\title{
Occurrence, Distribution, Epidemiology, Cultivar Reaction, and Management of Rice Blast Disease in California
}

\author{
C. A. Greer and R. K. Webster, Department of Plant Pathology, University of California, Davis 95616
}

\begin{abstract}
Greer, C. A., and Webster, R. K. 2001. Occurrence, distribution, epidemiology, cultivar reaction, and management of rice blast disease in California. Plant Dis. 85:1096-1102.

Rice blast, caused by Pyricularia grisea, was first found in California in 1996. Disease surveys have shown the blast disease is spreading at a moderate rate in California rice fields. Although no effective major resistance genes are known to occur in widely grown commercial California cultivars, there appear to be differences among the cultivars with respect to field susceptibility to the pathogen. $P$. grisea was recovered from rice crop residue and commercial seedlots which are suggested as possible sources of initial P. grisea inoculum in California rice fields. Examination of weather data indicates that environmental conditions in California riceproducing areas are permissive for rice blast but generally not optimal for epidemic development. Spore trapping determined that the majority of $P$. grisea conidia are generally not released until approximately 6:00 A.M. and would not have sufficient time for infection before leaf wetness periods end. Azoxystrobin showed positive results with respect to reduction of neck blast incidence and yield increases in small-plot and large-scale fungicide trials.
\end{abstract}

Rice blast, caused by Pyricularia grisea (Cooke) Sacc. (teleomorph, Magnaporthe grisea (T.T. Hebert) Yaegashi \& Udagawa), has the potential to cause severe crop losses in rice where environmental conditions are favorable for disease development. Yield losses may exceed $50 \%$ over large areas in some parts of the world (24) and estimated yield reductions in individual fields have been reported as high as 20 to $60 \%$ in the southern United States (23). P. grisea may infect most aboveground parts of the plant, but neck blast and panicle blast are the most damaging phases of the disease (24) and have been shown to significantly reduce yield, grain weight, and milling quality (30).

Rice blast is widespread throughout the rice-growing regions of the world and has been reported in more than 85 countries $(1,24,26,28)$. Interestingly, it has been pointed out on more than one occasion in the past that California is one of the few areas with extensive rice cultivation where the disease has not been reported $(24,28)$. Rice blast is considered endemic in southern U.S. rice production and has been reported in South Carolina, Louisiana, Arkansas, Texas, Florida, Mississippi, and Hawaii $(8,26)$. In 1996, rice blast was

Corresponding author: R. K. Webster

E-mail: rkwebster@ucdavis.edu

This work was supported by a grant from the California Rice Research Board.

Accepted for publication 22 June 2001.

Publication no. D-2001-0730-01R

(C) 2001 The American Phytopathological Society identified in California for the first time in the state's 85-year history of rice cultivation (10).

In general, long periods of leaf wetness, high relative humidity, and temperatures of 17 to $28^{\circ} \mathrm{C}$ favor rice blast development (33). Important processes in the disease cycle include sporulation, germination, and infection. Sporulation of $P$. grisea is favored by relative humidity $\geq 89 \%$, optimal temperatures of 25 to $28^{\circ} \mathrm{C}$, and a minimum of $4 \mathrm{~h}$ of leaf wetness $(15,24,32)$. Under optimal conditions, conidiophores and the first conidia were produced 4 to $6 \mathrm{~h}$ after dew formation and the conidia were released shortly thereafter $(15,32)$. Optimal conditions for $P$. grisea conidial germination were 92 to $96 \%$ relative humidity and temperatures of 25 to $28^{\circ} \mathrm{C}(15,24,33)$. In water, conidial germination may occur within $3 \mathrm{~h}$ (13). Leaf wetness of 7 to $14 \mathrm{~h}$ is essential for infection of rice by $P$. grisea $(3,12,13,32,35)$.

Seed, crop residue, and secondary hosts have all been reported as possible sources of $P$. grisea primary inoculum $(1,18,24$, 28,32). Some researchers believe that infested seed does not play a role in initiating epidemics (32), whereas others have evidence that it may be very important $(17,19)$. Transmission of $P$. grisea from seed to seedling has been demonstrated $(6,17,21)$. However, transmission of $P$. grisea from seed to seedling is reported to be difficult under the water-seeded conditions that are primarily used in California $(17,21)$. Rice crop residue is also thought to be an important source of primary inoculum for rice blast $(18,24,29)$. Secondary hosts have been reported as possible sources of inoculum, but the evi- dence is less convincing than for crop residue or seed $(18,20,28)$. Inoculations of rice under experimental conditions with isolates of $P$. grisea from weeds have resulted in successful (20) and unsuccessful (27) cross-inoculations. Borromeo et al. (4) found that DNA polymorphisms suggest that $P$. grisea isolates from rice and weed hosts have a common ancestry, but weed hosts do not provide inoculum for rice.

Resistant cultivars $(22,24)$ and fungicides $(2,15,32)$ are commonly used throughout the world to control rice blast. Planting resistant cultivars is the primary method of managing rice blast in many areas of the world (24), but as many as five fungicide applications may be made in areas where conditions are favorable for severe epidemics $(2,15)$. At the time of the discovery of rice blast in California, there were no known effective blast resistance genes in widely grown California cultivars and no fungicides were registered for use on rice in California. Azoxystrobin (Quadris 2.08 SC) was granted an emergency exemption (Section 18) in 1997 and 1998 and full registration (Section 3) in 1999 for the management of rice blast disease in California.

With the occurrence of rice blast in California, research to determine how this disease would affect rice under the California culture system and climatic conditions was initiated. The objectives of this research were to determine the extent of disease spread, possible sources of overwintering inoculum, effect of environmental conditions during the growing season, and susceptibility of California cultivars to $P$. grisea. In addition, the efficacy of azoxystrobin was tested for the control of rice blast disease in California.

\section{MATERIALS AND METHODS}

Distribution of rice blast in California. The distribution of rice blast disease was determined in 1996 by field examination and laboratory confirmation of suspected neck blast samples. A survey started during harvest, near the end of September 1996, consisted of driving through rice growing regions and stopping periodically to inspect fields for neck blast in Glenn, Colusa, Butte, Sutter, and Yolo Counties. In 1997, 1998, and 1999, fields known to be infested with $P$. grisea in previous years were inspected throughout the season, but efforts were also made in searching for rice blast outside of the known infested area. Panicle neck nodes and leaves exhibiting 
rice blast symptoms were placed on three pieces of moist filter paper in glass petri dishes and incubated for 2 days under continuous fluorescent lighting at room temperature to promote sporulation of the fungus. Identification of $P$. grisea was made with a dissecting microscope and based upon the production of characteristic conidia. In addition to the survey, specific fields and samples were inspected at the request of growers, Pest Control Advisors, County Farm Advisors, County Agricultural Commissioners, and the California Department of Food and Agriculture to confirm the presence of rice blast in area fields.

Possible sources of inoculum. Seed. Commercial seedlots were tested for the presence of $P$. grisea using the blotter method recommended by the International Rules for Seed Testing (11). Rice seed samples $(0.5$ to $1.5 \mathrm{~kg}$ ) were collected from storage bins for testing. Two samples of 400 seed from each seedlot were tested for the presence of $P$. grisea and the mean of these two tests was reported as the percentage of infested seed. Commercial seed producers submitted 121 seedlots for testing in 1996 and six seedlots in 1997. Foundation seedlots grown at the California Rice Experiment Station during the 199699 seasons were also tested for $P$. grisea.

Crop residue. Rice crop residue was collected in the spring just prior to ground preparation for the 1997, 1998, and 1999 growing seasons from fields where blast was known to have occurred during the previous season. Panicle neck node and tiller node samples were randomly selected and rinsed with running water for $1 \mathrm{~h}$ and patted dry with paper towels. Rinsed nodes were incubated on moist filter paper in glass petri dishes for $72 \mathrm{~h}$ under continuous fluorescent lighting at $25^{\circ} \mathrm{C}$ to promote sporulation of $P$. grisea. Presence of $P$. grisea was confirmed by examination with a dissecting microscope.

Secondary hosts. Surveys for possible infection of secondary hosts in and around rice fields were conducted prior to and throughout the 1997-99 growing seasons. Lesions from broadleaf and grassy weed species were collected from approximately 10 fields each year in blast-infested areas and examined for $P$. grisea. Samples of 15 to 30 lesions were examined for each of approximately 50 lesion types each year. Species examined included but were not limited to Echinochloa spp., Typha spp., Cyperus difformis, Leptochloa fascicularis, Scirpus mucronatus, Echinochloa spp., Cynodon dactylon, Sagittaria montevidensis subsp. calycina, S. longiloba, Heteranthera limosa, and Ammannia spp.

Environmental conditions. Weather data. Weather data were examined from California Irrigation Management Information System (CIMIS) weather stations in Colusa (Colusa County) and Orland (Glenn County) near rice blast-infested areas for the 1996 and 1997 growing seasons, as well as the 1994 and 1995 growing seasons when rice blast was not yet observed. The data included daily maximum and minimum temperature, maximum and minimum relative humidity, precipitation, and daily average wind speed and direction. Longterm 30-year averages from National Oceanic and Atmospheric Administration weather stations for daily maximum and minimum temperature as well as precipitation were also examined. Data were viewed to determine if there were any apparent deviations from previous weather patterns that would favor rice blast.

Microclimate data, including temperature, relative humidity, leaf wetness, precipitation, wind speed, and wind direction, were collected at the top of the crop canopy in six rice fields (Colusa, Glenn, and Butte Counties) by in-field stations, manufactured by Adcon Telemetry, Inc. (Boca Raton, FL), in 1998 and 1999. Stations were situated 12 to $20 \mathrm{~km}$ apart in fields within and outside of the rice blast-infested area. Data were examined to determine if weather conditions favored rice blast development in these areas and if there were any differences among the sites.

Spore sampling. Relative abundance and temporal presence of airborne $P$. grisea inoculum were monitored at four sites where weather data were being collected during the 1998 and 1999 growing seasons. Rotorod Model 20 samplers (Sampling Technologies, Inc., Minnetonka, MN) were placed at the edge of the field approximately $80 \mathrm{~cm}$ above the water surface at the top of the crop canopy. Spores were sampled for $30 \mathrm{~min}$ each day at 2:00 A.M., 6:00 A.M., or both. Sampling rods were changed every 2 days and brought to the lab for microscopic observation. $P$. grisea conidia were counted on a 22-mm length of each 1.52-mm wide collector rod. The total air volume sampled was $1.3 \mathrm{~m}^{3}$, as calculated by the manufacturer's instructions, during the 1-h sampling period over 2 days. The density of conidia was calculated for each sampling period and weather data from Adcon stations were examined to determine if any factors were associated with spore presence and density.

Susceptibility of California cultivars. In 1997 and 1998, the relative susceptibility of California rice cultivars to neck blast was compared in University of California Cooperative Extension regional cultivar trials established within commercial fields and planted within two days of the commercial planting. Trials were randomized complete block designs with four replications (3.05-by-6.1-m plots) per cultivar. Two identical trials, consisting of 9 commercial cultivars and 11 advanced breeding lines, were evaluated in Colusa and Glenn Counties in 1997. One trial consisting of 9 commercial cultivars and 11 advanced breeding lines was evaluated in Colusa County in 1998. Percent neck blast was determined by random samples and counts within a standard template for each plot in 1997. A 27-cm-diameter sampling ring was placed randomly at four locations approximately $0.75 \mathrm{~m}$ in from the edge of each plot. In 1998, percent neck blast was determined by counting the total number of panicles with neck blast in five random samples of five panicles at 10 locations approximately $0.75 \mathrm{~m}$ in from the edge of each plot. Percent neck blast was calculated for each plot and data were analyzed using analysis of variance. Cultivar means were further analyzed using the least significant difference (LSD) method of means separation.

Chemical control of rice blast. Seed treatment with sodium hypochlorite. Studies to determine the efficacy of sodium hypochlorite soaks to eliminate $P$. grisea from seed were carried out at various concentrations and soak times. Household bleach $(5.25 \% \mathrm{NaOCl})$ and Sani-Clean (12.5\% NaOCl; Birko Corp., Henderson, $\mathrm{CO})$ were tested for efficacy in seed treatments. Naturally infested seed of cvs. M201 and M-202 were used in these experiments. Seed samples of 20 to $250 \mathrm{~g}$ were soaked in 0 to $3.2 \% \mathrm{NaOCl}$ solutions for 1 to $24 \mathrm{~h}$. A sample of 400 seed from each treatment was tested for $P$. grisea using the blotter method, as previously described. Approximately 100 to 400 seed were placed between two layers of moist tissue paper supported by Plexiglas and placed in a humid chamber to determine the germination rate for seed from each treatment. Percent germination was determined after 7 days and a general assessment of seedling growth was made visually after 10 days. Chi-square analysis was used to evaluate $P$. grisea incidence and seed germination data.

Fungicide trials. In 1998, six small-plot field trials were established to investigate rate and timing of azoxystrobin applications for control of rice blast. One field was planted with Calmochi-101 and the remaining five fields were planted with $\mathrm{M}$ 202. Treatments were (i) azoxystrobin at $0.224 \mathrm{~kg}$ a.i./ha applied once at $50 \%$ boot split, (ii) azoxystrobin at $0.224 \mathrm{~kg}$ a.i./ha applied once at 60 to $90 \%$ heading, (iii) azoxystrobin at $0.224 \mathrm{~kg}$ a.i./ha applied at $50 \%$ boot split plus 60 to $90 \%$ heading, (iv) azoxystrobin at $0.336 \mathrm{~kg}$ a.i./ha applied once at $50 \%$ boot split, (v) azoxystrobin at $0.336 \mathrm{~kg}$ a.i./ha applied once at 60 to $90 \%$ heading, (vi) azoxystrobin at $0.336 \mathrm{~kg}$ a.i./ha applied at $50 \%$ boot split plus 60 to $90 \%$ heading, and (vii) control, not treated. Treatments were applied in 187 liters of $\mathrm{H}_{2} \mathrm{O}$ per hectare at 35 psi with a $\mathrm{CO}_{2}$-powered two-man spray boom using a randomized complete block design with three replications. Plots were 3.05 by $6.1 \mathrm{~m}$ with a 2.29-by-6.1-m strip harvested from the middle of each plot using a SWECO 324 plot combine. Percent neck blast was 
determined by cutting a sample of 15 to 25 tillers at five locations $0.35 \mathrm{~m}$ from the edge of each plot. Percent neck blast, yield at $14 \%$ moisture, and milling quality were determined for each plot. Data were analyzed by analysis of variance and means were separated using the LSD method where applicable.
In 1997, evaluation of the efficacy of azoxystrobin also was made in two fields where growers made commercial applications of the fungicide in Colusa and Glenn Counties. The Colusa County field (cv. M204) received azoxystrobin at $0.224 \mathrm{~kg}$ a.i./ha at 70 to $90 \%$ heading on a $45.75-\mathrm{m}$ strip at the edge of the field applied by

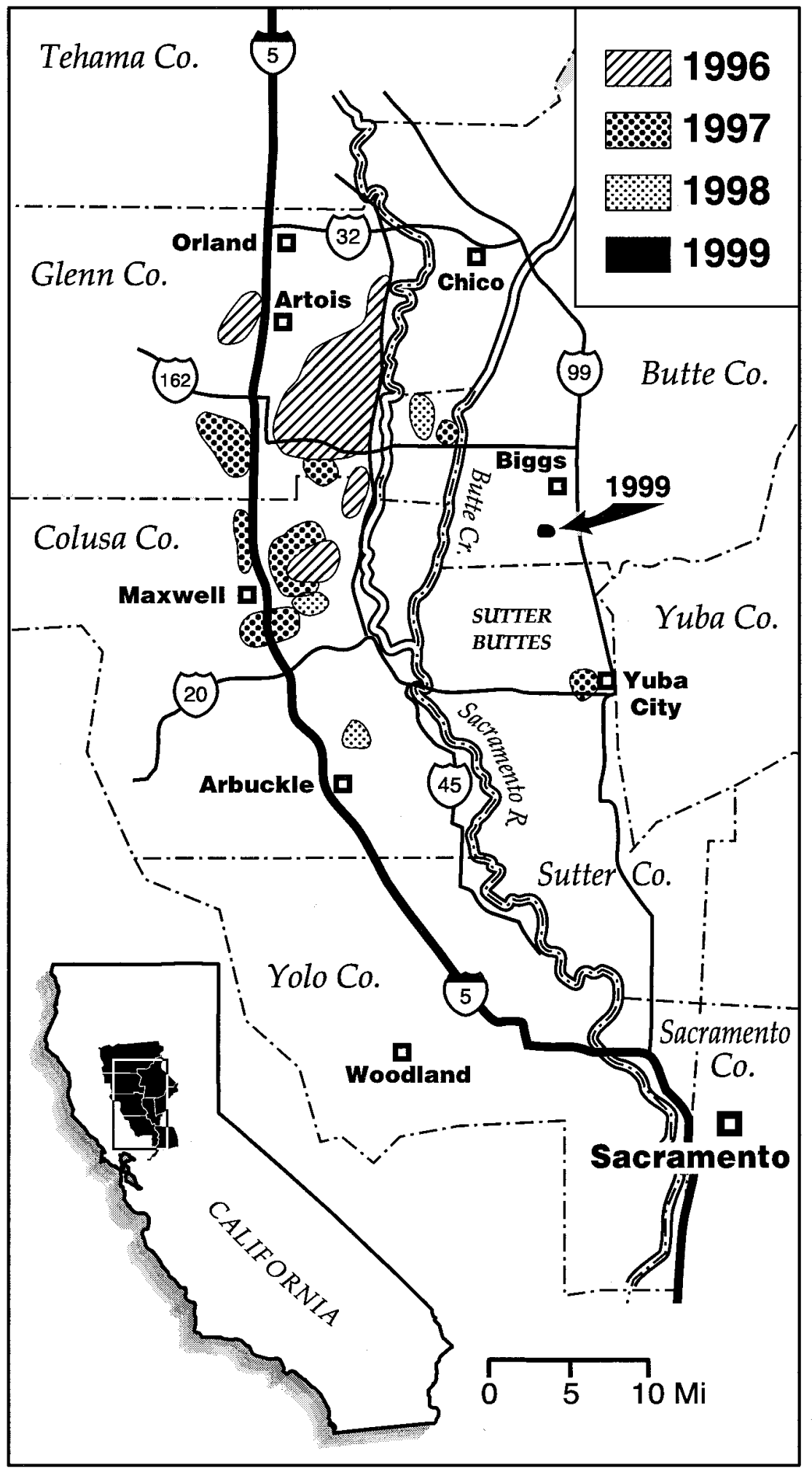

Fig. 1. Distribution of rice blast in California rice fields. Year of initial identification of blast infested area is indicated. airplane. The remainder of the field was untreated. A 54.9-by-3.05-m plot was staked in the treated and untreated areas with a buffer zone of $15 \mathrm{~m}$ between them. Neck blast incidence was evaluated by examining samples of 15 to 25 tillers cut randomly from 10 locations within each of three $18.3-\mathrm{m}$ sections of each plot. Nine 2.29-by-6.1-m strips were harvested from each treatment as previously described. Percent neck blast, yield at $14 \%$ moisture, milling quality, and percent infested seed were determined for each sampling unit. Data were analyzed by analysis of variance and means were separated using the LSD method where applicable.

The Glenn County site (cv. M-201) consisted of three areas within a grower's field that received no treatment (1.17 ha), azoxystrobin at $0.224 \mathrm{~kg}$ a.i./ha at $50 \%$ boot split (0.62 ha), or azoxystrobin at $0.224 \mathrm{~kg}$ a.i./ha at $50 \%$ boot split plus $70 \%$ heading (0.59 ha). Azoxystrobin was applied by airplane. Each treatment area was divided into three sections and incidence of neck blast was determined based on a sample of 15 to 25 tillers at 10 random locations from each section. Percent neck blast was determined for each section and data were analyzed by analysis of variance and means were separated using the LSD method. Treatment areas were harvested separately by the grower and total yield at $14 \%$ moisture was calculated for each. Yield data was not statistically analyzed because there was only one value per treatment.

\section{RESULTS}

Distribution of rice blast in California. The areas where rice blast was confirmed to occur during the 1996-99 growing seasons are shown in Figure 1. Based on confirmed infested fields, rice blast has generally been limited to Glenn and Colusa Counties, with the exceptions of initial identifications in distant fields in Sutter County (1997) and Butte County (1999). Rice blast tended to occur in the same areas in subsequent years. The 1996 field survey identified 27 infested fields in Glenn County (95 inspected), 6 in Colusa County (100 inspected), 0 in Butte County (116 inspected), 0 in Sutter County (150 inspected), and 0 in Yolo County (47 inspected). In addition to the survey, rice blast was confirmed in several other fields in Glenn and Colusa Counties. According to county agricultural commissioners, confirmed fields infested with $P$. grisea totaled approximately 3,200 ha in Glenn and Colusa Counties in 1996 and 23,000 ha in Glenn, Colusa, and Sutter Counties in 1997.

Possible sources of inoculum. Of 121 seedlots tested from the 1996 growing season, 15 were positive for $P$. grisea in at least one of two assays for the pathogen. Only M-201, M-202, and M-204 seedlots tested positive. Positive seedlots had a 
range of 0.125 to $2.75 \%$ infested seed. All but two of the positive samples had $0.50 \%$ infested seed or less, with the majority at $0.125 \%$. Eight samples tested positive $(0.25 \%)$ in one assay and negative in the other. All samples from outside of the known infested area resulted in negative tests for $P$. grisea. Samples from within the known infested area resulted in both positive and negative tests. The six seedlots tested from the 1997 growing season were from a known $P$. grisea-infested area. All but one of these seedlots tested positive for the presence of $P$. grisea in each of the two tests. Positive seedlots had a range of 0.25 to $5.625 \%$ infested seed. Foundation rice seed grown in Butte County at the California Rice Experiment Station, where no rice blast had been observed, tested negative for $P$. grisea in each of the 4 years.

Recovery of $P$. grisea from crop residue in the spring following the 1996 season was difficult because the samples were collected from a field where residue had been incorporated by discing in the fall. Residue was colonized by many saprophytes that covered the samples in a very short period of time after subjecting them to humid conditions. $P$. grisea was identified on crop debris, but in less than $1 \%$ of the tissue samples examined. Residue collected randomly in the spring of 1999 from a moderately infested 1998 field yielded $4.5 \%$ infected panicle neck nodes.

When residue was collected in the spring of 1998 from a field severely affected by rice blast in 1997, the pathogen was easily recovered from this material. Symptomatic panicle and tiller nodes often yielded sporulation when placed in humid chambers. Residue from stripper-harvested areas and conventionally harvested areas both harbored $P$. grisea prior to preparation of the ground for planting. Stripperharvested areas of the field contained straw standing erect throughout the winter, whereas conventionally harvested areas contained cut straw laying on the soil surface. Stripper-harvested residue yielded $P$. grisea from $27 \%$ of panicle neck nodes and $19 \%$ of tiller nodes. Conventionally harvested residue yielded $P$. grisea from $22 \%$ of panicle neck nodes and $18 \%$ of tiller nodes.

Leaf spots from many weed and grass species in and around rice fields were examined for the presence of $P$. grisea. The rice blast pathogen was not found to be causing leaf spots or lesions on any of the non-rice plant material examined prior to or throughout the 1997-99 growing seasons.

Environmental conditions. Weather data. Examination of weather data from CIMIS stations revealed no major deviations in weather patterns that would explain the occurrence of rice blast in 1996. Daily maximum and minimum temperature patterns of 1996 and 1997 were not noticeably different from those of 1994 and
1995. Maximum temperatures were more variable early in the season during the months of May and June and often deviated 5 to $15^{\circ} \mathrm{C}$ above or below the longterm 30-year averages of 78 to $92^{\circ} \mathrm{C}$ for each of the years examined. Daily maximum and minimum relative humidity was variable throughout each of the 199497 seasons, with 75 to $100 \%$ maximums and 15 to $40 \%$ minimums common. There were very few precipitation events during each of the years examined. Overall, there were approximately 10 days of rainfall that occurred mostly during cool temperatures (10 to $21^{\circ} \mathrm{C}$ ) in April and May of each growing season.

Analysis of weather data from Adcon weather stations in California rice fields during 1998 and 1999 showed that periods of 10 to $16 \mathrm{~h}$ of leaf wetness and relative humidity $>90 \%$ were common during the growing season, particularly during July, August, and September. Temperature and relative humidity data collected by a CIMIS station above irrigated turf and an Adcon station situated in a rice field were compared. Temperature measurements did not deviate more than 1 to $3^{\circ} \mathrm{C}$ at both locations, but daily maximum and minimum relative humidity readings were higher in the rice field, especially during the warmer part of the day when relative humidity was often 50 to $70 \%$, compared with 20 to $50 \%$ over irrigated turf.

A typical 48-h period of weather data collected at a Colusa County site is shown in Figure 2. Leaf wetness began at approximately 10:00 P.M. and ended at approximately 12:00 P.M. during this pe- riod. In general, leaf wetness and periods of relative humidity $>90 \%$ persisted for 12 to $16 \mathrm{~h}$ at each of the sites. Temperatures generally ranged from a maximum of 27 to $38^{\circ} \mathrm{C}$ to a minimum of 13 to $22^{\circ} \mathrm{C}$.

Spore sampling. No rice blast or very low disease pressure was observed at most of the spore trapping locations during the 1998 and 1999 seasons. No $P$. grisea spores were trapped in locations where rice blast was not observed. Where very low disease pressure was present, spores were only trapped at very low concentrations ( 0 to 2 spores $/ \mathrm{m}^{3}$ ) during the growing season.

In fields where moderate rice blast pressure was present, long leaf wetness periods (14 to $18 \mathrm{~h}$ ) and warmer mean temperatures $\left(18\right.$ to $\left.22^{\circ} \mathrm{C}\right)$ during the leaf wetness period resulted in higher $P$. grisea conidia production. An example of spore trapping data in relation to leaf wetness duration and mean temperature during leaf wetness period from the Colusa County is shown in Figure 3. P. grisea spores were collected during all sampling periods. Longer leaf wetness periods occurred later in the season. A greater number of $P$. grisea conidia were trapped at 6:00 A.M. than at 2:00 A.M. Spores were trapped during each sampling period between $4 \mathrm{Au}$ gust and 24 September 1998 at the 6:00 A.M. sampling time. Spore concentrations ranged from 0.77 to 279 spores $/ \mathrm{m}^{3}$ with a mean of 106.6 spores $/ \mathrm{m}^{3}$ and a median of $101.2 \mathrm{spores} / \mathrm{m}^{3}$. Spores were often not detected at 2:00 A.M. and spore concentrations ranged from 0 to 2.31 spores $/ \mathrm{m}^{3}$.

Susceptibility of California cultivars. In general, neck blast field susceptibility
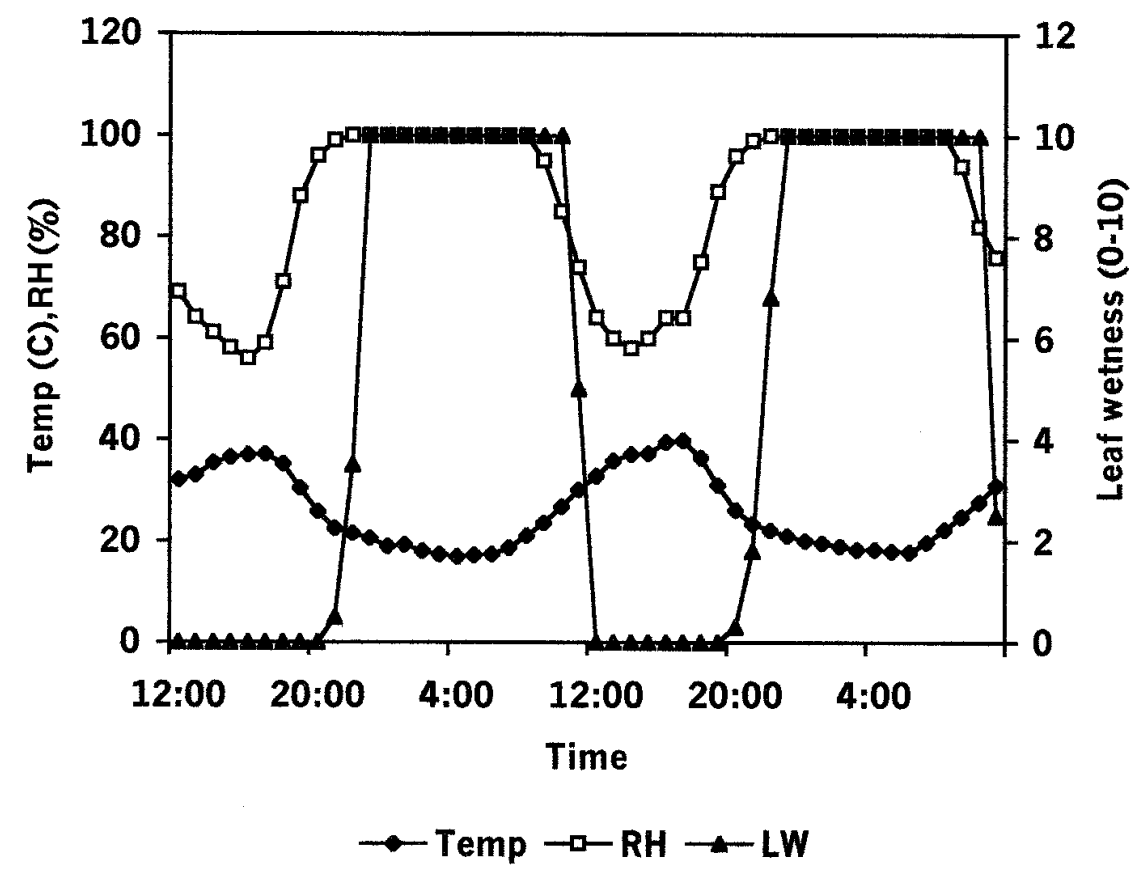

Fig. 2. Example of 48-h period of Adcon data for 1 August, 12:00 P.M. through 3 August, 12:00 P.M., 1998 for a Colusa County rice field. Temperature, relative humidity, and leaf wetness are represented. Sensors were located at the top of the crop canopy. Leafwetness is measured on a scale of 0 to 10 with $0=$ dry and $10=$ wet. 


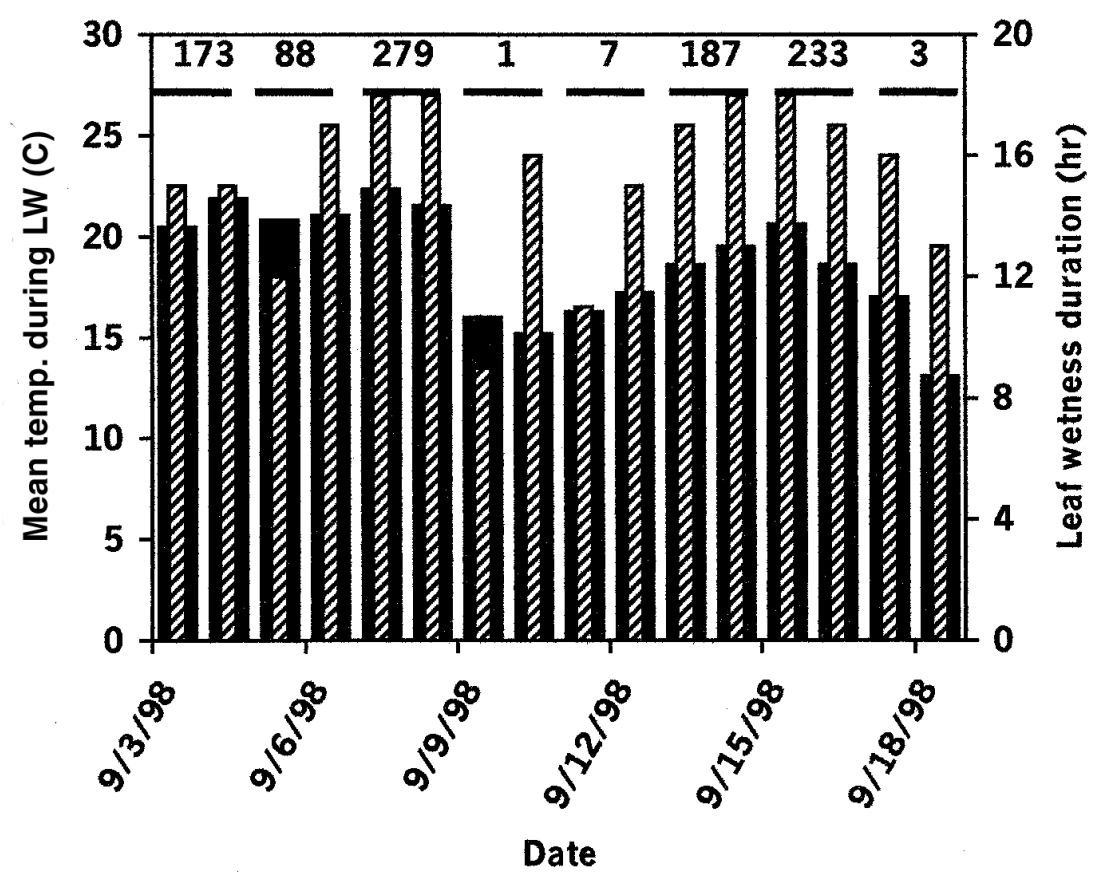

Temp $\boldsymbol{Q} \mathrm{LW}$ duration

Fig. 3. Pyricularia grisea spore trapping data in relation to leaf wetness duration and mean temperature during leaf wetness period in Colusa County. Bar indicates the number of days in the spore sampling period and value represents the number of $P$. grisea spores $/ \mathrm{m}^{3}$ of air sampled from 6:00 to 6:30 A.M. during each sampling period. Air was sampled at a rate of 1.3 $\mathrm{m}^{3} / \mathrm{h}$.

Table 1. Evaluation of relative neck blast susceptibility of California rice cultivars and advanced breeding lines in regional variety trials

\begin{tabular}{|c|c|c|c|}
\hline \multirow[b]{3}{*}{ Cultivar/line } & \multicolumn{3}{|c|}{ Percent neck blast $^{\mathrm{z}}$} \\
\hline & \multicolumn{2}{|c|}{ Colusa County } & \multirow{2}{*}{$\begin{array}{c}\text { Glenn County } \\
1997\end{array}$} \\
\hline & 1997 & 1998 & \\
\hline $94-Y-615$ & $33.6 \mathrm{a}$ & $7.6 \mathrm{bcd}$ & $5.6 \mathrm{bcd}$ \\
\hline M-201 & $32.3 \mathrm{a}$ & 6.1 bcde & $6.3 \mathrm{bcd}$ \\
\hline $96-Y-55$ & $29.8 \mathrm{a}$ & $8.8 \mathrm{bc}$ & $6.8 \mathrm{cb}$ \\
\hline $96-Y-480$ & $27.9 \mathrm{ab}$ & $1.7 \mathrm{de}$ & $5.5 \mathrm{bcd}$ \\
\hline L-204 & $20.4 \mathrm{bc}$ & $0.9 \mathrm{e}$ & 4.3 bcde \\
\hline L-203 & $20.4 \mathrm{bc}$ & $2.6 \mathrm{cde}$ & $3.6 \mathrm{bcde}$ \\
\hline $95-Y-629$ & $19.1 \mathrm{bcd}$ & $\ldots$ & 3.1 bcde \\
\hline M-204 & $17.9 \mathrm{~cd}$ & 3.3 bcde & 3.9 bcde \\
\hline $92-Y-624$ & $16.9 \mathrm{cde}$ & 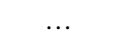 & $11.7 \mathrm{a}$ \\
\hline S-102 & $16.2 \mathrm{cde}$ & $2.2 \mathrm{de}$ & 3.3 bcde \\
\hline 95-Y-356 & $14.9 \mathrm{cdef}$ & 5.9 bcde & $7.8 \mathrm{ab}$ \\
\hline $96-Y-5$ & 13.2 cdefg & & $2.6 \mathrm{cde}$ \\
\hline $94-\mathrm{Y}-40$ & $11.2 \mathrm{cdefgh}$ & $0.9 \mathrm{e}$ & 3.7 bcde \\
\hline M-202 & $10.5 \mathrm{defgh}$ & 4.2 bcde & 4.7 bcde \\
\hline $96-Y-203$ & $7.9 \mathrm{efgh}$ & $0.0 \mathrm{e}$ & $2.8 \mathrm{cde}$ \\
\hline $96-Y-90$ & $6.7 \mathrm{fgh}$ & $0.1 \mathrm{e}$ & $2.1 \mathrm{cde}$ \\
\hline M-103 & $4.2 \mathrm{gh}$ & $1.5 \mathrm{de}$ & $2.8 \mathrm{cde}$ \\
\hline Calmochi-101 & $4.1 \mathrm{gh}$ & $2.0 \mathrm{de}$ & $0.4 \mathrm{e}$ \\
\hline S-201 & $2.8 \mathrm{~h}$ & $1.7 \mathrm{de}$ & $1.9 \mathrm{de}$ \\
\hline $96-Y-341$ & $2.6 \mathrm{~h}$ & $0.4 \mathrm{e}$ & $1.4 \mathrm{de}$ \\
\hline $95-Y-214$ & $\ldots$ & $26.9 \mathrm{a}$ & $\ldots$ \\
\hline $96-Y-420$ & $\ldots$ & $9.4 \mathrm{~b}$ & $\ldots$ \\
\hline $96-Y-253$ & $\ldots$ & 5.7 bcde & $\ldots$ \\
\hline $97-Y-613$ & $\ldots$ & $0.6 \mathrm{e}$ & $\ldots$ \\
\hline $97-Y-315$ & $\ldots$ & $0.1 \mathrm{e}$ & $\ldots$ \\
\hline $\operatorname{LSD}(P=0.05)$ & 9.4 & 6.4 & 4.8 \\
\hline
\end{tabular}

${ }^{\mathrm{z}}$ Means in each column followed by the same letter are not significantly different $(P \leq 0.05)$ according to Fisher's least significant difference (LSD) test. Values are means of four replications in each trial. rankings of California cultivars were quite consistent between locations and years. Percent neck blast on currently grown California cultivars and advanced breeding lines in these trials are shown in Table 1. There was considerably heavier disease pressure at the Colusa County site than at the Glenn County site in 1997. In general, the rankings of the cultivars were quite consistent between locations and years except for line 92-Y-624. M-201 appeared to be the most susceptible of the commercial cultivars currently grown in California. M-202, currently the most widely grown cultivar in the rice blast-infested area, was less susceptible to neck blast in each of the trials. M-103, Calmochi-101, S-201, and line 96-Y-341 were among the least susceptible cultivars.

Chemical control of rice blast. Seed treatment with sodium hypochlorite. Attempts to eliminate $P$. grisea from infested seed with sodium hypochlorite seed soaks were not successful at concentrations nondetrimental to seed. Low concentrations of sodium hypochlorite seed soaks resulted in increases in germination rates of treated seed. However, sodium hypochlorite concentrations and soak times needed to eliminate $P$. grisea from infested seed resulted in stunted and chlorotic seedlings. A $0.8 \%$ sodium hypochlorite soak for $24 \mathrm{~h}$ and a $3.2 \%$ sodium hypochlorite soak for $4 \mathrm{~h}$ were effective in eliminating detectable $P$. grisea in the tested seed samples, but germination rates were reduced from $>90 \%$ to $<75 \%$ and seedling health was visibly reduced.

1998 fungicide trials. The incidence of rice blast in small-plot fungicide trials was generally low $(<8 \%)$. Where a moderate level of disease occurred, percent neck blast was reduced $(P=0.0009)$ by $\geq 50 \%$ with azoxystrobin applications at 0.224 or $0.336 \mathrm{~kg}$ a.i./ha applied at $50 \%$ boot-split or $50 \%$ boot-split plus 60 to $90 \%$ heading. Although most applications of azoxystrobin resulted in yield increases of 225 to $675 \mathrm{~kg} / \mathrm{ha}$ more than the control, the differences were not statistically significant. Effect of azoxystrobin applications on milling quality was negligible.

There was a visible difference between the treated and untreated areas of a field where a grower in Colusa County applied azoxystrobin. Percent neck blast was significantly reduced $(P=0.0002)$ with one application of azoxystrobin from 78 to $24 \%$. Yield was significantly higher $(P=$ $0.0342)$ in the treated area $(8,857 \mathrm{~kg} / \mathrm{ha})$ than in the untreated area $(8,045 \mathrm{~kg} / \mathrm{ha})$. Percent seed infested with $P$. grisea was significantly greater $(P=0.0001)$ in the untreated area $(24.2 \%)$ as compared with the treated area $(5.6 \%)$.

Incidence of neck blast was significantly reduced $(P=0.001)$ in a Glenn County field with one $(11.5 \%$ neck blast) or two (8.7\% neck blast) commercial applications of azoxystrobin as compared with the un- 
treated control $(36.5 \%)$. Total treated areas yielded 9,441 kg/ha with one application of azoxystrobin and $9,045 \mathrm{~kg} / \mathrm{ha}$ with two applications, as compared with $8,187 \mathrm{~kg} / \mathrm{ha}$ for the untreated control.

\section{DISCUSSION}

It is likely that the rice blast pathogen was recently introduced into California. All California $P$. grisea isolates tested thus far have been determined to be of one pathogenic race, IG-1 (9). Although rice blast was first identified in 1996, the fact that it was found on more than 3,240 ha suggests it was introduced earlier. Rice blast appears to be spreading at a moderate rate in California, with the exception of its discovery in Sutter County (1997) and Butte County (1999). A much larger acreage was most likely reported in 1997 than in 1996 because the disease was identified much earlier in the season and there were more people aware of its presence.

It is clear that currently grown California rice cultivars are susceptible to rice blast. In fact, researchers in the southern United States frequently use California cultivar M-201 as spreader rows in blast nurseries and susceptible controls in cultivar trials $(5,19)$. Leaf blast appeared to be more severe in 1996 than in subsequent years. Large areas of plants killed by leaf blast were often seen in fields of M-201, less often in fields of M-204, and rarely in fields of M-202. The incidence of neck blast at the end of the season usually appeared to be related to the amount of leaf blast occurring during the season, although in some fields where little leaf blast was observed there was a significant amount of neck blast. These observations are likely due to airborne inoculum from neighboring fields when infected fields were at the most susceptible stage of maturity for neck blast to occur. More leaf blast resulted in the production of larger populations of conidia to infect panicles as they emerged. In 1996, field observations were that cv. M-201 was more severely affected by neck blast than other cultivars grown in the area. These observations were confirmed by results of cultivar trial ratings for neck blast in 1997 and 1998. Differences in cultivar trial ratings may have been influenced by environmental conditions and inoculum presence at the time of heading, but differences in relative susceptibility to neck blast were observed among cultivars with similar heading dates and were also observed in commercial fields over several years. Because of the performance of M201, most growers shifted to the cultivation of M-202 in 1997. The severe reduction of M-201 plantings may have been a significant factor in the reduction of rice blast severity following the 1996 season.

Approximately $10 \%$ of the California seedlots tested from the 1996 growing season were infested with $P$. grisea at low levels. The initial two rice blast-infested fields observed in Sutter County in 1997 are approximately $8 \mathrm{~km}$ apart, farmed by the same grower, and are at least 25 to 35 $\mathrm{km}$ from the original $P$. grisea-infested area. Both fields were planted with M-201 certified seed from a seedlot grown in the rice blast-infested area of Colusa County. It is likely that seed was the primary source of inoculum in these fields. Transmission of $P$. grisea from seed to seedling is reported to be very low or nonexistent under the water-seeded conditions primarily used in California $(17,21)$. However, many growers temporarily drain the water from fields shortly after seeding to promote seedling establishment and obtain better efficacy from herbicide applications. This practice may provide conditions favorable for transmission of $P$. grisea from seed to seedling. In addition, many seeds planted by airplane fall onto levees or soil that is not completely submerged. $P$. grisea may sporulate on infested seed under these conditions and serve as a source of primary inoculum in areas where rice blast has not been observed, which emphasizes the need to avoid using infested seed in areas not known to be infested.

Rice crop residue is thought to be an important source of primary inoculum for rice blast $(18,24,29)$. P. grisea was easily recovered from residue in infested California fields prior to ground preparation in the spring. Residue that was incorporated in the fall was more decomposed and yielded the pathogen less frequently than residue left standing in the field or lying on the soil surface. We believe rice crop residue is probably the most significant source of primary inoculum in rice blast-infested areas of California. Although $P$. grisea has not yet been observed on other hosts near California rice fields, the role of secondary hosts in the epidemiology of rice blast in California remains unknown.

It appears that environmental conditions in California rice-producing areas are permissive for rice blast but generally not optimal for epidemic development. There was much speculation that the occurrence of rice blast in 1996 was due to unusual weather conditions. However, examination of weather data and the reoccurrence of rice blast disease in 1997 to 1999 do not support this belief. In the Philippines, peak conidia release was at 1:00 to 3:00 A.M. during the dry season with temperatures of 25 to $30^{\circ} \mathrm{C}$ (25). However, Kim et al. found that conidia were released in a single peak at 6:00 to 7:00 A.M. during clear conditions and in two to three peaks between 1:00 and 8:00 A.M. during continuous cloudy conditions (16). Relative humidity remained $\geq 93 \%$ during the cloudy period, whereas it dropped below this level during the day during the clear period. Results in California agree with these findings because many more conidia were trapped at 6:00 A.M. than at 2:00 A.M. and cloudy conditions rarely occur in rice-pro- ducing areas of California during the ricegrowing season (mid-April to October).

Typical leaf wetness periods of $14 \mathrm{~h}$ in California rice fields are more than sufficient for conidia production; however, peak conidia release is typically at 6:00 A.M. This would allow approximately 4 to $6 \mathrm{~h}$ of leaf wetness for germination and infection, which would be inadequate at temperatures during that time period. The length of the required leaf wetness period for infection is dependent upon the temperature. Barksdale et al. (3) found that $12.2,9.7$, and $7.7 \mathrm{~h}$ of dew were required for infection at $15.6,21.1$, and $26.7^{\circ} \mathrm{C}$, respectively. Khan et al. (12) found required minimum dew periods of 14,12 , and $10 \mathrm{~h}$ at $18.3,21.1$, and $26.7^{\circ} \mathrm{C}$, respectively. Yoshino described the average infection time of a conidial population $(y)$ with the parabola $y=0.062 x^{2}-2.98 x+$ 48.21, where $x$ is the temperature during the incubation period (35). If leaf wetness ends before infection is completed, the process is terminated (32). All conidia are not produced at the same time; therefore, a very small percentage may be produced early enough to allow low levels of infection. It is possible that periods of cloudy conditions or rain would result in higher relative humidity and earlier production of conidia in California rice fields. Conidia produced earlier in the leaf wetness period would have a much better chance for successful infection. The exception to the obstacle of insufficient leaf wetness for infection may be seen in cases of the collar rot phase and neck blast which occur later in the growing season when free moisture periods are longer in California.

Leaf collars form a natural reservoir where water collects from dew periods and may allow a longer wetness and high humidity period. The panicle emerges from the flag leaf over a period of 3 to 6 days and the panicle neck node must pass through the collar. These tissues are succulent and susceptible to rice blast infection. Kato et al. (14) suggested that it took 3 to 5 days for panicle emergence, and infected apical spiklets may serve as inoculum for fresh panicles and neck nodes. New leaf lesions are rarely seen late in the season as tissue becomes more resistant with age and as temperatures rise above $31^{\circ} \mathrm{C}(31,34)$. In fact, significant amounts of collar and neck blast may be found in California fields where leaf blast incidence is minimal or not observed.

Planting resistant cultivars is the primary method of managing rice blast in many areas of the world (24). Development of effective resistant cultivars that may be grown in California is under way but will take several years. Although no major resistance genes effective against race IG-1 of $P$. grisea are known to occur in widely grown California cultivars, there does appear to be some limited field resistance that may be useful until that time. 
Azoxystrobin is currently the only registered fungicide for rice in California. Results of fungicide trials indicate that this compound may be an effective control measure for rice blast. Timing of fungicide applications is critical and is targeted at protecting the panicle as it emerges from the flag leaf. Azoxystrobin is an effective inhibitor of spore germination and is most effective when used as a protectant prior to infection (7). The results of small plot trials were promising with respect to neck blast incidence and yield; however, large variations among plots and relatively low disease incidences in 1997 to 1999 have made it difficult to make firm conclusions. Even so, substantial yield increases, milling quality improvement, and percent neck blast reductions have been measured in large-scale airplane-applied trials, indicating a need for further testing.

\section{ACKNOWLEDGMENTS}

We thank S. Scardaci for assistance with field experiments.

\section{LITERATURE CITED}

1. Agarwal, P. C., Mortensen, C. N., and Mathur, S. B. 1989. Seed-borne diseases and seed health testing of rice. Tech. Bull. No. 3, Phytopathological Papers No. 30. CAB International Mycological Institute, Kew, U.K.

2. Ahn, S. W., and Rubiano, M. 1984. Methods and timing of fungicide application to control rice blast $(\mathrm{Bl})$ under favorable upland conditions in Columbia. Int. Rice Res. Newsl. 9:1213.

3. Barksdale, T. H., and Asai, G. N. 1965. Minimum values of dew period and temperature required for infection by Pyricularia oryzae. (Abstr.) Phytopathology 55:503.

4. Borromeo, E. S., Nelson, R. J., Bonman, J. M., and Leung, H. 1993. Genetic differentiation among isolates of Pyricularia infecting rice and weed hosts. Phytopathology 83:393-399.

5. Cartwright, R. D., Parsons, C. E., Ross, W. J., Lee, F. N., and Templeton, G. E. 1997. Rice disease monitoring in Arkansas. Arkansas Rice Research Studies 1996. Univ. Ark. Agric. Exp. Stn. Res. Ser. 456:81-89.

6. Chung, H. S., and Lee, C. U. 1983. Detection and transmission of Pyricularia oryzae in ger- minating rice seed. Seed Sci. Technol. 11:625637.

7. Clough, J. M., and Godfrey, C. R. A. 1998. The strobilurin fungicides. In: Fungicidal Activity: Chemical and Biological Approaches to Plant Protection. D. Hutson and J. Miyamoto, eds. John Wiley \& Sons, Ltd., Chichester, U.K.

8. Farr, D. F., Bills, G. F., Chamuris, G. P., and Rossman, A. Y. 1989. Fungi on Plants and Plant Products. American Phytopathological Society Press, St. Paul, MN.

9. Greer, C. A. 1999. Occurrence and nature of rice blast disease caused by Pyricularia grisea in California. Ph.D. dissertation. University of California, Davis.

10. Greer, C. A., Scardaci, S. C., and Webster, R. K. 1997. First report of rice blast caused by Pyricularia grisea in California. Plant Dis. 81:1094.

11. International Seed Testing Association. 1985. International Rules for Seed Testing, Rules 1985. S. R. Draper chief ed. International Seed Testing Association, Zurich.

12. Kahn, R. P., and Libby, J. L. 1958. The effect of environmental factors and plant age on the infection of rice by the blast fungus, Pyricularia oryzae. Phytopathology 48:25-30.

13. Kato, H. 1974. Epidemiology of rice blast disease. Rev. Plant Prot. Res. 7:1-20.

14. Kato, H., Sasaki, T., and Koshimizu, Y. 1971. The role of diseased spikelets as the secondary inoculum source in the infection chain of rice blast. Rev. Plant Prot. Res. 4:9899.

15. Kim, C. K. 1994. Blast management in high input, high yield potential, temperate rice ecosystems. In: Rice Blast Disease. R. S. Zeigler and S. A. Leong, eds. CAB International, Wallingford, U.K.

16. Kim, C. K., Min, H. S., and Yoshino, R. 1990. Epidemiological studies of rice blast disease caused by Pyricularia grisea Cavara (III) Diurnal pattern of conidial release and dispersal under natural conditions. Ann. Phytopathol. Soc. Jpn. 56:315-321.

17. Lamey, H. A. 1970. Pyricularia oryzae on rice seed in the United States. Plant Dis. Rep. 54:931-935.

18. Lee, F. N. 1994. Rice breeding programs, blast epidemics and blast management in the United States. In: Rice Blast Disease. R. S. Zeigler and S. A. Leong, eds. CAB International, Wallingford, U.K.

19. Long, D. H., TeBeest, D. O., and Lee, F. N. 1997. The effect of nitrogen fertilization on the epidemiology of rice blast disease in small plots in Arkansas. Arkansas Rice Research
Studies 1996. Univ. Ark. Agric. Exp. Stn. Res. Ser. 456:94-108.

20. Mackill, A. O. 1986. New hosts of Pyricularia oryzae. Plant Dis. 70:125-127.

21. Manandhar, H. K., Lyngs Jorgensen, H. J., Smedegaard-Petersen, V., and Mathur, S. B. 1998. Seedborne infection of rice by Pyricularia oryzae and its transmission to seedlings. Plant Dis. 82:1093-1099.

22. Marchetti, M. A., Lai, X., and Bollich, C. N. 1987. Inheritance of resistance to Pyricularia oryzae in rice cultivars grown in the United States. Phytopathology 77:799-804.

23. Marchetti, M. A., Rush, M. C., and Hunter, W. E. 1976. Current status of rice blast in the Southern United States. Plant Dis. Rep. 60:721-725.

24. Ou, S. H. 1985. Rice Diseases. 2nd ed. Commonwealth Mycological Institute, Kew, U.K.

25. Ou, S. H., Awoderu, V. A., and Ebron, T. T., Jr. 1974. Daily periodicity of the conidia release of Pyricularia oryzae over a rice blast nursery. Plant Dis. Rep. 58:544-548.

26. Parthasarathy, N., and Ou, S. H. 1965. Opening address: international approach to the problem of blast. In: The Rice Blast Disease. John Hopkins Press, Baltimore, MD.

27. Prabhu, A. S., Filippi, M. C., and Castro, N 1992. Pathogenic variation among isolates of $P$. oryzae affecting rice, wheat, and grasses in Brazil. Trop. Pest Manage. 38:367-371.

28. Rao, K. M. 1994. Rice Blast Disease. Daya Publishing House, Delhi, India.

29. Reddy, A. P. K., and Bastawsi, O. A. 1989. Survival of the rice blast pathogen in the Nile Delta of Egypt. (Abstr.) Phytopathology 79:1217.

30. Surek, H., and Beser, N. 1997. Effect of blast disease on yield. Int. Rice Res. Newsl. 22:2526.

31. Suzuki, H. 1975. Meteorological factors in the epidemiology of rice blast. Annu. Rev. Phytopathol. 13:239-256.

32. Teng, P. S. 1994. The epidemiological basis for blast management. In: Rice Blast Disease. R. S. Zeigler and S. A. Leong, eds. CAB International, Wallingford, U.K.

33. Webster, R. K., and Gunnell P. S., eds. 1992. Compendium of Rice Diseases. American Phytopathological Society, St. Paul, MN.

34. Yeh, W. H., Bonman, J. M., and Lee, E. J. 1989. Effects of temperature, leaf wetness duration, and leaf age on partial resistance to rice blast. J. Plant Prot. Trop. 6:223-230.

35. Yoshino, R. 1974. Ecological studies on the infection in rice blast epidemics. Dew temperature and sequent change of infection rates. Ann. Phytopathol. Soc. Jpn. 39:186. 